(c) American Dairy Science Association, 2007.

\title{
Adherence and Efficacy of an External Teat Sealant to Prevent New Intramammary Infections in the Dry Period
}

\author{
G. H. Lim, ${ }^{\star}$ K. E. Leslie, ${ }^{\star}$ D. F. Kelton, ${ }^{\star}$ T. F. Duffield, ${ }^{\star}$ L. L. Timms, $†$ and R. T. Dingwell ${ }^{1}$ \\ *Department of Population Medicine, Ontario Veterinary College, Guelph, Ontario, Canada N1G 2W1 \\ †Department of Animal Science, lowa State University, Ames 50011
}

\begin{abstract}
The efficacy and adherence of an external teat sealant applied at drying off was evaluated in 2 studies between 1997 and 1999. At drying off, 2 quarters were randomized to receive intramammary dry-cow antibiotic therapy, and the remaining 2 quarters were treated with either a single or double application of external teat sealant. Approximately $3 \mathrm{~d}$ before calving, all teats that had been dipped at drying off were redipped in a single coating of teat sealant. Adherence of the teat sealant was scored for the first 2 wk after drying off, and physical traits of the teat skin and teat ends were recorded. Quarter milk samples were collected $1 \mathrm{wk}$ before drying off, at drying off, 0 to $7 \mathrm{~d}$, and 14 to $21 \mathrm{~d}$ postcalving. Somatic cell counts were determined from quarter samples taken at d 7 and 14 to $21 \mathrm{~d}$ after calving. Data were analyzed from 172 dry periods of 162 cows. The mean time of sealant adherence following drying off application was $3 \pm 0.13 \mathrm{~d}$. Double sealant application significantly increased the duration of adherence by $0.67 \mathrm{~d}$. Teats that had teat sealant applied twice at drying off and that had up to $3 \mathrm{~d}$ of adherence had the lowest linear score (LS) at 14 to $21 \mathrm{~d}(1.89 \pm 0.31)$ of all quarters. The LS of quarters that received antibiotic therapy only was $2.27 \pm 0.19$. The majority of intramammary infections identified at drying off were caused by the minor pathogens, coagulase-negative staphylococci and Corynebacterium bovis (51 and 23\%, respectively). The results from this study indicate that duration of sealant adherence to the teat-end should be considered when evaluating the impact of teat sealant treatment at drying off on the level of infection after calving. Double sealant application, cooler seasons, and longer teat lengths were associated with a significant increase in the duration of sealant adherence to the teat-end.
\end{abstract}

Key words: teat sealant, dry period, adherence, linear score

Received August 11, 2006.

Accepted September 27, 2006.

${ }^{1}$ Corresponding author: dingwell@uoguelph.ca

\section{INTRODUCTION}

Dry-cow management continues as an area of active research and innovation (Dingwell et al., 2003). The current North American practice, recommended by the National Mastitis Council (NMC) for the elimination of any existing infections and the prevention of new IMI during the dry period, is blanket dry-cow antibiotic therapy (DCT). Blanket DCT is successful in decreasing the incidence of new IMI during the dry period, particularly from gram-positive organisms, and eliminates many existing IMI present at the end of lactation (Smith et al., 1985a; Schukken et al., 1993). Although DCT is effective, it has limitations. Therapeutic levels of antibiotics are present in the mammary gland for a limited period (Bradley and Green, 2001), and most commercially available DCT in North America are targeted specifically against gram-positive bacteria. As a result, quarters are left unprotected and susceptible to other types of new IMI in the latter part of the dry period, particularly gram-negative infections.

Availability of internal teat sealants has created a new area of research and has been the topic of multiple clinical trials worldwide over recent years (Huxley et al., 2002; Godden et al., 2003; Sanford et al., 2006). Internal teat sealers function as inert physical barriers in the teat cistern, with the goal of preventing the penetration of bacteria from the environment into the udder. As nonantibiotic devices designed to seal and protect the teat canal for the entire dry period, proper aseptic technique during intramammary administration at drying off is critical. Teat sealers can be used alone in noninfected cows to prevent new IMI and decrease the use of DCT. Alternatively, they can be used in conjunction with DCT to provide protection beyond that achieved with DCT alone.

In contrast, results reporting the use of external sealants during the dry period have not been published in the peer-reviewed literature. When studying external sealants applied at drying off and during the peripartum periods with barrier dips made for lactating cows, researchers have not generally observed significant reductions in the rate of new IMI in primiparous (Edinger et al., 2000) and multiparous cows (McArthur et al., 
1984; Matthews et al., 1988). Timms (2001) demonstrated that a key strategy in the application of external sealants is to apply the sealant as needed. This is particularly true in the prepartum period. Dipping teats once at dry-off and thereafter as often as needed prepartum (whenever the sealant has worn off) resulted in significantly reduced infection rates in heifers and cows. Recently, some benefit was observed when external teat sealants were applied prepartum to first-calf heifers (Acuna Pasuqualini et al., 2006). Adherence of the teat sealant was meager, suggesting that insufficient duration of adherence was a probable cause for the absence of any benefit (McArthur et al., 1984; Matthews et al., 1988). However, no effort was made to quantitatively assess the relationship between duration of sealant adherence and any of the measured outcomes.

The objective of this study was to determine quarterlevel and cow-level variables affecting duration of adherence when the sealant was applied at drying off. Another objective was to determine the impact of sealing teats at drying off on the infection status at calving. Finally, the impact of duration of sealant adherence to the teat-end was evaluated to assess the incidence of new IMI.

\section{MATERIALS AND METHODS}

\section{Herd Participation and Cow Enrollment}

Two research herds affiliated with the University of Guelph (Ontario, Canada) participated in this trial. These herds were the Elora Dairy Research Station (Elora, Ontario), and the Ponsonby Dairy Research Centre (Ponsonby, Ontario). The routine dry-cow housing, feeding, and management program was followed in each herd. This 2-yr trial began in May 1997, and finished in January 1999. All cows that had completed at least 1 full lactation entering the dry period were enrolled in this investigation. Some cows that had remained in the herd during the entire period and that were bred back in a timely manner were enrolled in successive dry periods.

\section{Treatment Protocol}

Following the last milking before drying off, treatment was randomly assigned among quarters within the same cow in a systematic manner. Two teats were infused with an approved dry-cow antibiotic formulation containing benzathene cloxacillin (DryClox; Wyeth Animal Health, Guelph, Ontario, Canada) using the partial insertion method of administration. The teats treated with DCT were then dipped with a $1 \%$ iodine solution. The remaining 2 teats were coated in a drycow teat sealant formulation containing polyether and polyurethane in a tetrahydrafuran base with benzoin gum (Stronghold; DeLaval, Kansas City, MO). Sealant application was carried out in accordance with the manufacturer's directions. Teats were first wiped with a dry towel to remove any moisture and dirt. Then the teat and teat-end were thoroughly cleaned with a cotton swab soaked with $70 \%$ isopropyl alcohol, and allowed to air dry. The sanitized teat was dipped into the sealant formulation using an applicator cup so that at least two-thirds of the teat was coated with sealant.

Three months following the commencement of the trial, an investigation was begun to assess the effect of double sealant application at drying off. Hence, 1 of the teats in the sealant group was dipped a second time. Duplicate sealant application occurred 3 to 5 min after the initial application. Therefore, treatments at drying off were: DCT ( $\mathrm{n}=345)$, single sealant application (single, $\mathrm{n}=219$ ), and double sealant application (double, $\mathrm{n}=124)$.

Approximately $3 \mathrm{~d}$ before the expected day of calving, cows were moved to a maternity pen. Teats that were dipped in sealant at drying off were dipped in sealant again after appropriate teat-end preparation. One coating of sealant was applied at this time.

\section{Recorded Variables}

The degree of sealant adherence to the teat was recorded once each day for the first 2 wk after drying off. Subsequent observations were made every week until the sixth week after drying off. Adherence was scored on a scale of 1 to 5 , with a score of 5 corresponding to a tightly covered teat, with very few or no signs of the sealant being shed. Conversely, a score of 1 corresponded to the sealant coating completely removed. If the sealant was almost completely worn off, but the teat end was still covered, this was a score of 2 . Light and early signs of removal to moderate or significant wear corresponded to scores of 4 and 3, respectively.

At drying off, physical traits of teats and teat-ends were observed by a single trained technician. These characteristics included teat-end shape, teat-end lesion, teat shape, teat length, and skin condition of the teat (Table 1; Britt and Farnsworth, 1996).

\section{Sampling Regimen}

Quarter milk samples were collected aseptically by a trained technician, according to the procedures outlined by NMC (1999). Loose dirt was first removed from teatends, which were then scrubbed clean with cotton swabs soaked in $70 \%$ alcohol. Initial streams of milk were discarded before sample collection. Quarter milk samples were collected from all enrolled cows at the follow- 
Table 1. Specific criteria for classifying the recorded physical teat characteristics

\begin{tabular}{lll}
\hline Outcome/variable & Level & Criterion \\
\hline Lesion & 1 & No callous, no lesion \\
& 2 & Raised callous ring, slight roughness \\
& 3 & Rough callous with hyperkeratosis \\
& 4 & Very rough callous, hyperkeratosis, and radial cracking \\
Shape & 5 & Severe everted teat-end lesion \\
& Cylinder & Uniform teat diameter \\
Length & Funnel & Narrower teat diameter toward the teat-end \\
& Wide & Wide, uniform teat diameter \\
& Short & Less than 2 inches \\
Skin & Average & 2 to 3 inches \\
& Long & More than 3 inches \\
& Normal & Supple smooth skin \\
& Dry & Scaling and roughness present \\
\hline
\end{tabular}

ing 4 times: 1) $7 \mathrm{~d}$ before drying off, 2) at drying off, 3) 0 to $7 \mathrm{~d}$ postcalving, and 4) 14 to $21 \mathrm{~d}$ postcalving. Samples were placed in cooler packs and transported to the laboratory for immediate culture for the presence of bacteria, and for subsequent SCC determination.

\section{Microbiological and Somatic Cell Counting Procedures}

Each quarter milk sample was assessed for bacteriological growth and analyzed for SCC at the University of Guelph Mastitis Research Laboratory. Culturing of samples followed the procedures of the NMC (1999). An inoculum of $0.01 \mathrm{~mL}$ of the sample was streaked onto a Columbia base agar containing $5 \%$ sheep blood, and $0.1 \mathrm{~mL}$ was streaked onto MacConkey agar. Plates were incubated for $48 \mathrm{~h}$ at $37^{\circ} \mathrm{C}$. Tentative diagnoses were based on colony characteristics, morphology, patterns of hemolysis, size, and gram staining. Gram-positive cocci and rods both underwent a catalase test to differentiate each morphology group into either staphylococci or streptococci. Staphylococcal isolates were tested for coagulase production with the tube coagulase test, and streptococcal isolates were subcultured on agar containing esculin, and underwent a CAMP test. Gram-negative isolates were tentatively diagnosed on gross appearance and reaction to an oxidase test and then a citrate test to differentiate Escherichia coli from Klebsiella spp. If a sample contained 3 or more different organisms, it was considered contaminated.

Concentrations of somatic cells were measured using a Fossomatic 215 electronic cell counter (Foss North America, Inc., Eden Prairie, MN), where the maximum allowable SCC reading was $9,999,000$ cells $/ \mathrm{mL}$.

\section{Data Calculations}

All data were entered and maintained in an Excel 2000 spreadsheet (Microsoft Corp., Redmond, WA). Du- plicate data entry was conducted to minimize data entry errors. To meet the objectives of the investigation, several outcomes were analyzed.

\section{Outcomes of Interest}

The number of days that the sealant covered the teatend was used to determine the factors affecting sealant adherence at drying off. Calculation for days of adherence was done so that sealants that were absent from the teat-end on the first day of observation had $0 \mathrm{~d}$ of adherence. Teat-ends that remained covered for $14 \mathrm{~d}$ of observation had $14 \mathrm{~d}$ of adherence. The log-transform of this outcome was modeled to facilitate statistical analysis, so that statistical tests based on normal distribution theory could be conducted. An adjustment factor of $0.5 \mathrm{~d}$ was added to observations of $0 \mathrm{~d}$ of adherence, so that the log-transformed value could be determined.

To determine the impact of treatment at drying off on the level of infection at calving, 2 outcomes were used. A major outcome was the SCC at 14 to $21 \mathrm{~d}$ postcalving. Linear SCC scores (LS) were used to facilitate statistical analysis, as calculated according to the following formula:

$$
=\frac{\log \left(\frac{s c c}{100,000}\right)}{\log 2}+3
$$

where log refers to the natural logarithm, $\log _{\mathrm{e}}$.

Quarter milk samples that could not be analyzed due to the presence of clots were assigned the maximum SCC reading $\left(9,999 \times 10^{3}\right.$ cells $\left./ \mathrm{mL}\right)$.

Pathogens that were cultured in the bacteriological analysis were identified as Staphylococcus aureus, Streptococcus agalactiae, environmental streptococci, coliforms, CNS, and Corynebacterium bovis. A quarter was defined as infected with 1 of these pathogens at drying off if that pathogen was cultured in at least 1 
of the 2 pre-dry period samples, whereas a quarter was defined as uninfected with that pathogen at drying off if neither of the pre-dry period samples were culture positive for that pathogen. A quarter was defined as uninfected with a particular pathogen at drying off, if 1 of the samples was missing culture results and the other was negative for that pathogen. Similar criteria were used to define infection status after calving.

In the subsequent analysis, only newly infected quarters (uninfected at drying off and infected after calving) and quarters that remained uninfected over the dry period (uninfected at drying off and uninfected after calving) with respect to environmental streptococcal and coliform pathogens were analyzed to determine the impact of treatment at drying off on the level of infection after calving.

\section{Descriptive and Statistical Analyses}

Descriptive analysis was carried out to identify general trends in the data. Univariate and multivariate analyses were conducted on the log-transform of days of sealant adherence, LS at 14 to $21 \mathrm{~d}$ postcalving, and new infection status after calving caused by environmental pathogens. All statistical analyses were carried out using SAS software (version 8.0; SAS Institute, Inc., Cary, NC).

Continuous outcomes (log-transform of days of sealant adherence and LS at 14 to $21 \mathrm{~d}$ postcalving) were analyzed using the MIXED procedure in SAS, and least squares regression was used in the univariate and multivariate analyses. Binary outcomes (new infection status caused by environmental streptococci and coliforms) were analyzed with the GENMOD procedure using logistic regression and specifying the binomial distribution and logit link.

For both continuous and discrete outcomes, parameter estimates and standard errors in the multivariate modeling were adjusted for the correlation among quarters using generalized estimating equations (Liang and Zeger, 1993). This was conducted by invoking the repeated statement in both SAS procedures. A compound symmetry covariance structure was specified to allow quarters from the same cow to be similarly correlated. In addition, the effects of herd and parity were forced into all multivariate models as fixed effects to adjust for confounding.

In the multivariate modeling, the statistical significance of each analyzed variable was evaluated using a forward stepwise selection process based on the likelihood ratio test. Biologically plausible interactions among these variables were considered. With the exception of treatment, herd, and parity, only variables that were associated with $P<0.20$ were included in the final model for each outcome. In the analysis of days of adherence, statistical significance was declared at $P$ $<0.05$, whereas in the analysis of LS and bacteriological outcomes, statistical significance was declared at $P<$ 0.10 . Model fit was assessed using the Akaike information criterion, as well as through an examination of the residuals to ensure that model assumptions were met.

\section{RESULTS}

A total of 688 quarters (172 dry periods, 162 cows) were available for consideration in this trial. All mature cows ending their first lactation or greater were eligible. Cows were excluded if they left the herd, and quarters were excluded from analysis if they had a chronic IMI that required DCT treatment. Of the total cows and quarters enrolled, 1 cow was removed from the study, and 156 quarters were excluded for missed samples, cow exclusion, inappropriate randomization, or missing SCC information. Most dry periods $(\mathrm{n}=133)$ were observed in the Elora herd. In both farms, fewer dry periods were observed in the winter $(n=29)$ months than in the summer $(n=50)$ due to the period of enrollment. Trends observed for the season of calving were similar to those observed for the season of drying off, with a lag of one season. Most enrolled cows had completed 1 or 2 full lactations. Only $6.4 \%$ of cows had completed 4 or 5 lactations. Therefore, levels 3,4 , and 5 were collapsed as $\geq 3$ lactations, and analyzed together.

The distribution of quarters observed for all recorded teat-level variables are presented in Table 2 . In both farms, the distribution of quarters observed for each teat-level variable was similar $(P>0.05)$. Because the decision to evaluate the effects of the double application of sealant occurred 3 mo after the trial had commenced, approximately 32 and $18 \%$ of quarters were dipped in sealant once and twice at drying off, respectively. Combined over both farms, most teat-ends were classified as pointed $(39.7 \%)$ or round (38.1\%). No teat-end lesions (lesion score 5) were observed in either farm, and because few teat-ends were classified as having a lesion score of 4 , subsequent analysis combined levels 3 and 4. Most teats were classified as having a cylindrical shape (70.8\% combined for both farms) and were of average length (78.3\% combined for both farms). None of the teats was classified as having rough skin.

\section{Adherence}

Only teats that were sealed at drying off provided data for analysis. The percentages of teat-ends covered with sealant by day of observation are presented in Figure 1. Teats dipped in sealant twice at drying off were protected for a longer period than teats that were 
Table 2. Distribution of enrolled quarters across the recorded teat-level variables by herd

\begin{tabular}{|c|c|c|c|c|c|c|}
\hline Variable & $\mathrm{n}$ & $(\%)$ & $\mathrm{n}$ & $(\%)$ & $\mathrm{n}$ & $(\%)$ \\
\hline \multicolumn{7}{|c|}{ Treatment at dry off } \\
\hline Antibiotics only & 267 & $(50.2)$ & 78 & $(50.0)$ & 345 & $(50.1)$ \\
\hline Sealant (single) & 169 & $(31.8)$ & 50 & $(32.1)$ & 219 & $(31.8)$ \\
\hline Sealant (double) & 96 & $(18.0)$ & 28 & $(17.9)$ & 124 & $(18.0)$ \\
\hline Total & 532 & $(100.0)$ & 156 & $(100.0)$ & 688 & $(100.0)$ \\
\hline \multicolumn{7}{|l|}{ Teat-end lesion } \\
\hline 1 & 173 & $(32.5)$ & 67 & $(43.0)$ & 240 & (34.9) \\
\hline 2 & 228 & $(42.9)$ & 56 & $(35.9)$ & 284 & $(41.3)$ \\
\hline 3 & 108 & $(20.3)$ & 17 & $(10.9)$ & 125 & $(18.2)$ \\
\hline 4 & 23 & $(4.3)$ & 8 & $(5.1)$ & 31 & $(4.5)$ \\
\hline 5 & 0 & $(0.0)$ & 0 & $(0.0)$ & 0 & $(0.0)$ \\
\hline Missing & 0 & $(0.0)$ & 8 & (5.1) & 8 & (1.2) \\
\hline Total & 532 & $(100.0)$ & 156 & $(100.0)$ & 688 & $(100.0)$ \\
\hline \multicolumn{7}{|l|}{ Teat-end shape } \\
\hline Funnel & 101 & $(19.0)$ & 44 & $(28.2)$ & 145 & $(21.1)$ \\
\hline Pointed & 231 & $(43.4)$ & 42 & $(26.9)$ & 273 & $(39.7)$ \\
\hline Round & 200 & (37.6) & 62 & $(39.8)$ & 262 & $(38.1)$ \\
\hline Missing & 0 & $(0.0)$ & 8 & $(5.1)$ & 8 & (1.2) \\
\hline Total & 532 & $(100.0)$ & 156 & $(100.0)$ & 688 & $(100.0)$ \\
\hline \multicolumn{7}{|l|}{ Teat shape } \\
\hline Cylinder & 366 & $(68.8)$ & 121 & $(77.6)$ & 487 & (70.8) \\
\hline Funnel & 157 & (29.5) & 23 & (14.7) & 180 & $(26.2)$ \\
\hline Wide & 9 & $(1.7)$ & 4 & $(2.6)$ & 13 & (1.9) \\
\hline Missing & 0 & $(0.0)$ & 8 & $(5.1)$ & 8 & (1.2) \\
\hline Total & 532 & (100.0) & 156 & $(100.0)$ & 688 & $(100.0)$ \\
\hline \multicolumn{7}{|l|}{ Teat skin condition } \\
\hline Normal & 416 & $(78.2)$ & 102 & $(65.4)$ & 518 & (75.3) \\
\hline Dry & 116 & (21.8) & 46 & $(29.5)$ & 162 & $(23.5)$ \\
\hline Rough & 0 & $(0.0)$ & 0 & $(0.0)$ & 0 & $(0.0)$ \\
\hline Missing & 0 & $(0.0)$ & 8 & (5.1) & 8 & (1.2) \\
\hline Total & 532 & $(100.0)$ & 156 & $(100.0)$ & 688 & $(100.0)$ \\
\hline \multicolumn{7}{|l|}{ Teat length } \\
\hline Short & 79 & (14.9) & 16 & (10.3) & 95 & $(13.8)$ \\
\hline Average & 414 & (77.8) & 125 & $(80.1)$ & 539 & (78.3) \\
\hline Long & 39 & $(7.3)$ & 7 & $(4.5)$ & 46 & $(6.7)$ \\
\hline Missing & 0 & $(0.0)$ & 8 & (5.1) & 8 & (1.2) \\
\hline Total & 532 & (100.0) & 156 & (100.0) & 688 & $(100.0)$ \\
\hline
\end{tabular}

dipped only once $(P<0.01)$. By $1 \mathrm{~d}$ of observation, $15.5 \%$ of sealant coatings in the once-dipped group had fallen off, whereas only $3.3 \%$ of sealants in the twice-dipped group had fallen off. In general, teats dipped twice were coated with sealant for approximately $1 \mathrm{~d}$ longer than

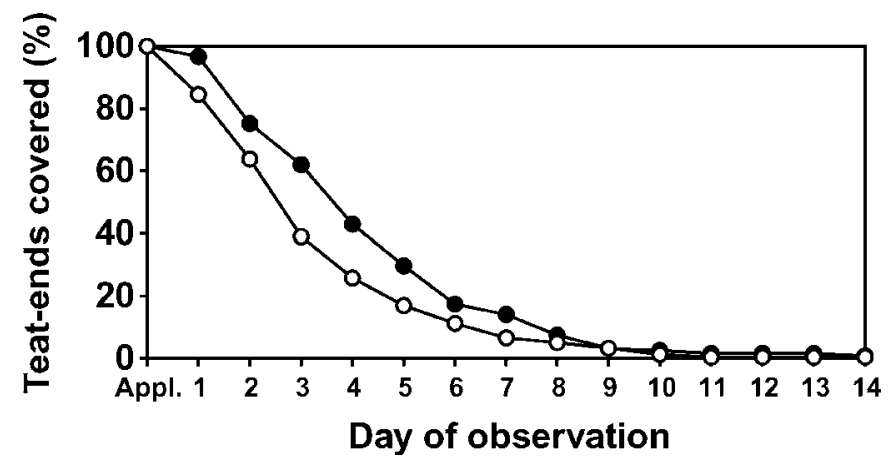

Figure 1. Percentage of teat-ends covered (score $>1$ ) for each day of observation in the dry period after having received either a single $(\bigcirc)$ or double $(-)$ application of external teat sealant. teats dipped only once. Of all the teats that were dipped in sealant twice at drying off, $43.0 \%$ were protected for more than $3 \mathrm{~d}$, whereas only $25.8 \%$ of teats in the oncedipped group were protected for more than $3 \mathrm{~d}$.

Univariate analysis of risk factors associated with adherence revealed that twice-dipped teats were protected longer than once-dipped teats $(3.57 \pm 0.23$ vs. $2.60 \pm 0.16 \mathrm{~d}$ ). Although this trend was observed in both farms, it was statistically significant in the Elora research herd. Mean adherence values for both treatment groups were higher in the Ponsonby research herd. The single and double treatment adherence in Elora was $2.27 \pm 0.16$ and $3.35 \pm 0.27 \mathrm{~d}$, respectively, compared with $3.80+0.42$ and $4.40+0.44 \mathrm{~d}$ in Ponsonby. With the exception of teat length, none of the measured teat characteristics was significantly associated with the duration of adherence. In both farms, short teats $(<4.4 \mathrm{~cm})$ remained protected by the sealant for a shorter period compared with longer teats (1.77 \pm 0.26 vs. $3.00 \pm 0.47 \mathrm{~d})$. Overall, average ( $2.82 \pm 0.17$ d) and long teats $(3.00 \pm 0.47 \mathrm{~d})$ were protected for a longer period $(P<0.05)$. 
LIM ET AL.

Table 3. Parameter estimates in the final multivariate model for the log-transform of duration of sealant adherence

\begin{tabular}{|c|c|c|c|c|c|}
\hline \multirow[b]{3}{*}{ Variable } & \multirow{2}{*}{\multicolumn{3}{|c|}{ Parameter }} & \multicolumn{2}{|c|}{ Least squares mean } \\
\hline & & & & \multirow{2}{*}{$\begin{array}{l}\text { Modeled } \\
\text { log-transformed } \\
\text { outcome }^{2}\end{array}$} & \multirow{2}{*}{$\begin{array}{l}\text { Duration of } \\
\text { sealant } \\
\text { adherence }(d)\end{array}$} \\
\hline & $\begin{array}{l}\text { Estimate } \\
\left(\log _{\mathrm{e}} \mathrm{d}\right)\end{array}$ & SE & $P$ & & \\
\hline \multicolumn{6}{|c|}{ Sealant application ${ }^{1}$} \\
\hline Double & 0.28 & 0.07 & $<0.01$ & $1.01^{\mathrm{a}}$ & 2.76 \\
\hline Single $^{2}$ & & & & $0.74^{\mathrm{b}}$ & 2.09 \\
\hline \multicolumn{6}{|c|}{ Season of drying off } \\
\hline Winter/spring & 0.39 & 0.10 & $<0.01$ & $1.07^{\mathrm{a}}$ & 2.91 \\
\hline Summer/fall ${ }^{2}$ & & & & $0.68^{\mathrm{b}}$ & 1.98 \\
\hline \multicolumn{6}{|l|}{ Teat length } \\
\hline Long/average & 0.29 & 0.11 & 0.01 & $1.02^{\mathrm{a}}$ & 2.78 \\
\hline Short $^{2}$ & & & & $0.73^{\mathrm{b}}$ & 2.07 \\
\hline Parity & & & 0.44 & & \\
\hline 1 & 0.16 & 0.12 & & 0.94 & 2.57 \\
\hline 2 & 0.12 & 0.13 & & 0.90 & 2.46 \\
\hline$\geq 3^{2}$ & & & & 0.78 & 2.19 \\
\hline \multicolumn{6}{|l|}{ Farm } \\
\hline Elora & -0.51 & 0.12 & $<0.01$ & $0.62^{\mathrm{a}}$ & 1.86 \\
\hline Ponsonby $^{2}$ & & & & $1.13^{\mathrm{b}}$ & 3.10 \\
\hline
\end{tabular}

Season of application at drying off was highly significant in both farms. Teats that were dipped during the winter and spring months (December to May) were protected with sealant for a longer period $(3.79 \pm 0.28 \mathrm{~d})$ than teats dipped during the summer $(2.35 \pm 0.26 \mathrm{~d})$ and fall $(2.52 \pm 0.21 \mathrm{~d})$ months $(P<0.05)$. Combined over both farms, the average duration of sealant adherence during the summer, fall, winter, and spring seasons were $2.35,2.52,3.79$, and $3.51 \pm 0.29 \mathrm{~d}$, respectively.

In the final multivariate model (Table 3), frequency of sealant application $(P<0.01)$, season of drying off $(P$ $<0.01)$, and teat length $(P=0.01)$ were associated with the log-transformation of days of sealant adherence. Parameter estimates for the final model, and corresponding estimates of the mean days of adherence for each of these variables are provided.

After adjusting for other effects in the model, dipping teats twice in sealant formulation was associated with a $0.67-d$ increase in adherence. No statistical difference was observed between average and long teats so the categories were combined. Combined over these categories, average and long teats were protected for $0.71 \mathrm{~d}$ longer than short teats. Similarly, no statistical differences were observed for teats dipped in sealant during the winter or spring seasons, as well as during the summer or fall seasons. Therefore, the appropriate levels were combined, and sealants that were applied during the winter or spring seasons (December to May) adhered to the teat-end $0.93 \mathrm{~d}$ longer than those that were applied during the summer or fall seasons (June to November).

Significant differences in adherence were observed between the herds. The mean duration of adherence was $1.24 \mathrm{~d}$ longer in the Ponsonby herd.

\section{LS at 14 to $21 d$ Postcalving}

In both herds, the mean LS was greatest in the sample taken at 0 to $7 \mathrm{~d}$ postcalving $(4.68 \pm 0.11)$, and lowest in the sample taken at 14 to $21 \mathrm{~d}$ postcalving $(2.22 \pm$ 0.10 ). The mean LS $1 \mathrm{wk}$ before drying off and at drying off were $3.52 \pm 0.09$ and $3.46 \pm 0.09$, respectively. To ensure that the level of udder health at drying off was similar across all levels of treatment, statistical comparisons of the mean LS associated with the sample collected at drying off were made. No significant differences were observed in the Elora and Ponsonby herds.

In the multivariate modeling of LS, duration of sealant adherence was evaluated when assessing the effect of treatment at drying off. Several parameterizations were evaluated for statistical significance. The parameterization that provided the best fit to the data was a variable treatment by time (TREAT_TIME) that had the following 5 levels: antibiotics only (DCT); single sealant application and duration of adherence between 0 and $3 \mathrm{~d}$ (single: 0 to 3 ); single sealant application and duration of adherence $\geq 4 \mathrm{~d}$ (single:4+); double sealant application and duration of adherence between 0 and 
Table 4. Parameter estimates in the final multivariate model for the linear score at 14 to $21 \mathrm{~d}$ postcalving

\begin{tabular}{|c|c|c|c|c|c|c|}
\hline \multirow[b]{2}{*}{ Variable } & \multicolumn{3}{|c|}{ Parameter } & \multicolumn{3}{|c|}{ Least squares means } \\
\hline & Estimate & $\mathrm{SE}$ & $P$ & Mean & SE & $\mathrm{n}$ \\
\hline TREAT_TIME $^{1}$ & & & 0.09 & & & \\
\hline Single:0-3 & 0.42 & 0.20 & & $2.69^{b}$ & 0.24 & 110 \\
\hline Single:4+ & -0.15 & 0.30 & & $2.12^{\mathrm{a}}$ & 0.31 & 45 \\
\hline Double:0-3 & -0.38 & 0.28 & & $1.89^{\mathrm{a}}$ & 0.31 & 48 \\
\hline Double:4+ & -0.09 & 0.29 & & $2.18^{\mathrm{a}}$ & 0.31 & 46 \\
\hline Dry-cow therapy ${ }^{2}$ & & & & $2.27^{\mathrm{a}}$ & 0.19 & 260 \\
\hline Linear score at drying off & & & $<0.01$ & & & \\
\hline$\geq 4$ & 0.80 & 0.21 & & $2.63^{\mathrm{a}}$ & 0.21 & 245 \\
\hline$<4^{2}$ & & & & $1.83^{\mathrm{b}}$ & 0.22 & 264 \\
\hline Season of calving & & & $<0.01$ & & & \\
\hline Summer/spring & 0.80 & 0.29 & & $2.63^{\mathrm{a}}$ & 0.23 & 273 \\
\hline Fall/winter ${ }^{1}$ & & & & $1.83^{\mathrm{b}}$ & 0.24 & 236 \\
\hline Parity & & & 0.11 & & & \\
\hline 1 & -0.70 & 0.38 & & 2.02 & 0.26 & 222 \\
\hline 2 & -0.79 & 0.39 & & 1.94 & 0.25 & 174 \\
\hline$\geq 3^{2}$ & & & & 2.72 & 0.32 & 113 \\
\hline Farm & & & 0.68 & & & \\
\hline Elora & 0.15 & 0.35 & & 2.30 & 0.18 & 399 \\
\hline Ponsonby $^{2}$ & & & & 2.16 & 0.31 & 110 \\
\hline
\end{tabular}

${ }^{\mathrm{a}, \mathrm{b}}$ Trait means with different superscripts are different $(P<0.05)$.

${ }^{1}$ The TREAT_TIME variable represents a combination of either a single or double treatment of teat sealant and the duration of adherence achieved: single:0-3 = single application, less than $3 \mathrm{~d}$ adherence; single:4+ = single application and $\geq 4 \mathrm{~d}$ adherence; double:0-3 = double application and less than $3 \mathrm{~d}$ adherence; double: $4+=$ double application and $\geq 4 \mathrm{~d}$ of adherence.

${ }^{2}$ This trait is the baseline for comparison for the derived parameter estimate.

$3 \mathrm{~d}$ (double:0 to 3); and double sealant application and duration of adherence $\geq 4 \mathrm{~d}$ (double:4+).

In the final multivariate model, TREAT_TIME $(P=$ $0.09)$, season of calving $(P<0.01)$, and LS at drying off $(P<0.01)$ were associated with the LS after calving. Parameter estimates and least squares means for the LS at 14 to $21 \mathrm{~d}$ postcalving associated with this model are provided in Table 4 . Teats in the "single:0 to 3" group were associated with the highest LS at 14 to 21 $\mathrm{d}$ postcalving (2.69). Linear score for the remaining levels of TREAT_TIME ranged from 1.89 to 2.27.

A high LS at drying off was associated with the LS after calving $(P<0.01)$. Season of calving had an effect on the LS after calving. In the multivariate modeling, no statistical difference in mean LS was found for cows that calved during the spring or summer seasons, and during the fall or winter seasons. Therefore, these levels were combined, and the mean LS for cows that calved during the spring or summer seasons was 0.80 higher than for cows that calved during the fall or winter seasons. With season of calving in the model, season of drying off was not statistically significant, and was therefore excluded from the final model. No significant differences were observed between the 2 farms for LS at calving or for parity.

\section{Bacteriological Analysis}

At drying off, the most common bacteria identified as causing an infection were CNS $(51.4 \%)$ and $C$. bovis
(22.7\%). The proportion of samples that were positive for a contagious pathogen was higher in the Ponsonby herd compared with the Elora herd at all 4 sampling intervals $(5.3,5.4,4.2$, and $4.0 \%$ vs. $2.8,2.5,2.9$, and $2.9 \%$, respectively, at $7 \mathrm{~d}$ before drying off, at drying off, 0 to $7 \mathrm{~d}$ postcalving, and 14 to $21 \mathrm{~d}$ postcalving. Streptococcus agalactiae was not cultured in any of the quarter milk samples collected in the Elora herd, but was identified in 6 quarters in the Ponsonby herd. In both herds, environmental streptococci were more frequently cultured than coliforms over all sampling intervals $(2.3,1.7,3.6$, and $2.1 \%$ vs. $0.3,0.5,2.4$, and $0.2 \%$, respectively, for the 4 sampling intervals).

The second outcome that was used to determine the impact of treatment at drying off was the number of new IMI caused by environmental pathogens at calving. Only quarters that were uninfected at drying off were used in the analysis. For new environmental streptococci, the number of uninfected quarters at drying off was 593, whereas for new coliform IMI, 604 quarters were uninfected.

There was a significant association between treatment assigned at drying off and new environmental streptococci infections after calving in the Elora herd (Table 5). In this herd, the proportion of quarters that were newly infected with environmental streptococci was highest in quarters that had been dipped in sealant only once $(6.1 \%)$, and lowest in quarters treated with antibiotics $(1.7 \%)$. A total of $2.3 \%$ of the quarters that 
Table 5. Proportion of new infections caused by environmental streptococci over the dry period for recorded teat-level variables, by herd

\begin{tabular}{|c|c|c|c|c|c|c|c|c|c|}
\hline \multirow[b]{2}{*}{ Trait } & \multicolumn{3}{|c|}{ Elora } & \multicolumn{3}{|c|}{ Ponsonby } & \multicolumn{3}{|c|}{ Both } \\
\hline & $\%^{1}$ & (n) & $P$ & $\%^{1}$ & (n) & $P$ & $\%^{1}$ & (n) & $P$ \\
\hline Treatment $^{2}$ & & & 0.06 & & & 0.77 & & & 0.21 \\
\hline Dry-cow therapy & $1.69^{\mathrm{a}}$ & (4) & & 8.20 & (5) & & 3.02 & $(9)$ & \\
\hline Single & $6.08^{\mathrm{b}}$ & (9) & & 7.89 & (3) & & 6.45 & (12) & \\
\hline Double & $2.33^{\mathrm{a}}$ & (2) & & 13.04 & (3) & & 4.59 & (5) & \\
\hline Teat-end shape & & & 0.26 & & & 0.03 & & & 0.02 \\
\hline Funnel & 5.68 & (5) & & 12.50 & (4) & & $7.50^{\mathrm{a}}$ & (9) & \\
\hline Pointed & 1.95 & (4) & & 0.00 & (0) & & $1.67^{\mathrm{b}}$ & (4) & \\
\hline Round & 3.41 & (6) & & 11.54 & (6) & & $5.26^{\mathrm{a}}$ & (12) & \\
\hline Teat-end lesion score & & & 0.81 & & & 0.09 & & & 0.34 \\
\hline 1 & 3.95 & (6) & & 8.89 & (4) & & 5.08 & (10) & \\
\hline 2 & 2.93 & (6) & & 12.00 & (6) & & 4.71 & (12) & \\
\hline$\geq 3$ & 2.63 & (3) & & 0.00 & $(0)$ & & 2.19 & (3) & \\
\hline Teat shape & & & 0.34 & & & 0.45 & & & 0.10 \\
\hline Cylinder & 3.49 & (11) & & 8.79 & (8) & & 4.68 & (19) & \\
\hline Funnel & 2.03 & (3) & & 4.35 & (1) & & 2.34 & (4) & \\
\hline Wide & 12.50 & (1) & & 25.00 & (1) & & 16.67 & (2) & \\
\hline Teat-skin condition & & & 0.22 & & & 0.36 & & & 0.06 \\
\hline Normal & 2.65 & (10) & & 6.67 & (5) & & 3.32 & (15) & \\
\hline Dry & 5.32 & (5) & & 11.63 & (5) & & 7.30 & (10) & \\
\hline Teat length & & & 0.68 & & & 0.49 & & & 0.86 \\
\hline Short & 3.03 & (2) & & 15.38 & (2) & & 5.06 & (4) & \\
\hline Average & 2.96 & (11) & & 7.92 & (8) & & 4.02 & (19) & \\
\hline Long & 6.06 & (2) & & 0.00 & (0) & & 5.41 & (2) & \\
\hline
\end{tabular}

${ }^{\mathrm{a}, \mathrm{b}}$ Row proportions within trait with different superscripts are different $(P<0.05)$.

${ }^{1}$ Respective to each classification level per variable, this refers to the proportion of uninfected quarters at drying off that were classified as a newly infected quarter over the dry period (n).

${ }^{2}$ Treatment administered at drying off: dry-cow antibiotic therapy, single or double application of external teat sealant.

had been dipped twice were newly infected. Treatment was not significantly associated with new IMI caused by environmental pathogens in the Ponsonby herd, or overall in both herds combined. New environmental streptococci infections were identified more frequently for funnel-shaped or round teat-ends $(P=0.02$, combined for both herds). None of the other measured teat characteristics was significantly associated with new environmental streptococci infections over the dry period in either farm.

Combined over both herds, teat-end lesion score was associated with the incidence of new coliform infections $(P<0.01 ; 4.2 \%$ of quarters with a teat-end lesion score of $\geq 3$ compared with only $0.4 \%$ of quarters with a lesion score of 2). When analyzed separately, this effect was not observed in the Elora or Ponsonby herds. No statistical associations were identified with any of the other recorded teat-level variables.

Season of drying off and season of calving were not statistically associated with new environmental streptococcal infections at calving in either herd. Although parity was statistically associated with new environmental streptococcal infections in the Elora herd, new environmental streptococcal infections occurred most frequently in cows that had completed $\geq 3$ lactations before entering the dry period (6.5\%) compared with parity 1 or 2 cows (2.6 and 1.5\%, respectively). Although the effect of parity was significant in the Ponsonby herd, no new environmental streptococcal infections were identified in cows that had completed 3 or more lactations ( 0 of 30 quarters). Combined over both farms, the effect of parity was not significant. Parameter estimates in the final multivariate model for new infections caused by environmental streptococci are provided in Table 6. After accounting for the correlation among quarters, and forcing in parity and herd as fixed confounding effects, TREAT_TIME was not significant in the final model.

In the multivariate modeling, only teat-end shape was associated with new environmental streptococcal infections after calving $(P<0.01)$. No statistical differences were observed for teat-end shape; therefore, the appropriate levels were combined. In particular, funnel-shaped or round teat-ends were 3.48 times more likely to develop a new IMI caused by environmental streptococcal infection after calving than pointed teat-ends.

In the final multivariate model for new infections caused by coliforms over the dry period, TREAT_TIME was not significant. Similar to the results for new IMI 
Table 6. Parameter estimates in the final multivariate model for the presence or absence of a quarter newly infected with environmental streptococci

\begin{tabular}{|c|c|c|c|c|c|c|}
\hline \multirow[b]{2}{*}{ Variable } & \multicolumn{3}{|c|}{ Parameter } & \multirow{2}{*}{$\begin{array}{l}\text { Odds } \\
\text { ratio }^{1}\end{array}$} & \multirow[b]{2}{*}{$\mathrm{SE}$} & \multirow{2}{*}{$\begin{array}{l}\text { New } \\
\text { infections } \\
\text { (n) }\end{array}$} \\
\hline & Estimate & $\mathrm{SE}$ & $P$ & & & \\
\hline TREAT_TIME $^{2}$ & & & 0.30 & & & \\
\hline Single:0-3 & 0.50 & 0.60 & & 1.65 & 0.99 & 6 \\
\hline Single:4+ & 1.59 & 0.55 & & 4.92 & 2.72 & 6 \\
\hline Double:0-3 & 0.76 & 0.71 & & 2.14 & 1.52 & 3 \\
\hline Double:4+ & 0.23 & 0.85 & & 1.26 & 1.08 & 2 \\
\hline Dry-cow therapy ${ }^{3}$ & & & & & & 8 \\
\hline Teat-end shape & & & $<0.01$ & & & \\
\hline $\begin{array}{l}\text { Funnel/round } \\
\text { Pointed }^{3}\end{array}$ & 1.25 & 0.58 & & 3.48 & 2.03 & $\begin{array}{r}21 \\
4\end{array}$ \\
\hline Parity & & & 0.91 & & & \\
\hline 1 & -0.15 & 0.55 & & 0.86 & 0.47 & 9 \\
\hline $\begin{array}{l}2 \\
>3^{3}\end{array}$ & -0.24 & 0.55 & & 0.79 & 0.43 & 9 \\
\hline $\begin{array}{l}\geq 3^{\circ} \\
\text { Farm }\end{array}$ & & & 0.20 & & & 7 \\
\hline Elora & -0.76 & 0.49 & & 0.47 & 0.23 & 15 \\
\hline Ponsonby $^{3}$ & & & & & & 10 \\
\hline
\end{tabular}

${ }^{1}$ Odds ratio of a new infection by environmental streptococci at calving (relative to baseline group).

${ }^{2}$ The TREAT_TIME variable represents a combination of either a single or double treatment of teat sealant and the duration of adherence achieved: single:0-3 = single application, less than $3 \mathrm{~d}$ adherence; single:4+ = single application and $\geq 4 \mathrm{~d}$ adherence; double: $0-3=$ double application and less than $3 \mathrm{~d}$ adherence; double:4+ = double application and $\geq 4 \mathrm{~d}$ of adherence.

${ }^{3}$ This level is taken to be the baseline for comparison for the derived parameter estimate, and the corresponding odds ratio.

caused by environmental streptococci, standard errors derived in these models were large and parameter estimates were highly unreliable. In the multivariate modeling, none of the analyzed variables was statistically associated with new coliform infections at calving.

\section{DISCUSSION}

\section{Adherence}

Combined over both treatment groups, the mean duration of sealant adherence to the teat-end was $2.95 \pm$ $0.13 \mathrm{~d}$. The mean duration was $2.6 \pm 0.16 \mathrm{~d}$ for a single application, and $3.57 \pm 0.23 \mathrm{~d}$ for a double application. This is superior to the results reported in previous studies that evaluated barrier teat dip products applied during the dry period (McArthur et al., 1984; Matthews et al., 1988). In one study, researchers observed that the sealants failed to persist for $24 \mathrm{~h}$ (Matthews et al., 1988). Furthermore, in the current study, double sealant application at drying off significantly improved the duration of sealant adherence to the teat-end. Compared with teats that were dipped only once at drying off, the double application significantly increased the mean days of adherence by $0.67 \mathrm{~d}$. This is the first study documenting this effect. The thicker coating achieved by double application may have enhanced the integrity of the seal, thus making it less likely to roll down the teat. Despite the duration of adherence reported in this study, the protection afforded by external teat sealers still does not compare with properly inserted internal teat sealers, which can remain in the teat canal for the entire dry period.

Of all the recorded teat characteristics, only teat length was significantly associated with duration of adherence to the teat-end at drying off. Because increased intramammary pressure during involution causes the teat canal to dilate (Comalli et al., 1984), teat characteristics evaluated on the day of dry-off may have changed subsequently over the ensuing crucial period. Therefore, statistical associations between duration of adherence and teat characteristics may not have been detectable under the current study design. Furthermore, even with parity in the model, teat length was significantly associated with sealant adherence to the teat-end. Therefore, although teat characteristics may reflect the physical changes associated with increasing parity, parity certainly does not fully account for teat characteristics. Therefore, teat characteristics should always be considered in any investigation of teat sealant adherence.

Application of the dry-cow teat sealant during the winter and spring seasons (December to May) demonstrated superior adherence compared with application during the summer and fall seasons (June to November). Beneficial results of cooler temperatures were observed in other studies in which sealants were refriger- 
ated before application (Hemling et al., 1998; Creasey et al., 2002). It was proposed that a thicker barrier was formed as a result of the increased viscosity of the sealant at cooler temperatures.

The mean duration of adherence was different between the Elora and Ponsonby herds. Results from other studies indicate that the duration of sealant adherence to the teat-end varies between herds (Hemling et al., 1998; Edinger et al., 2000; Creasey et al., 2002). Specific herd management practices, including different environmental conditions, may account for some of these differences.

\section{LS After Calving}

Somatic cell counts are frequently used as an indicator of udder infection. A threshold of 200,000 cells $/ \mathrm{mL}$, which is equivalent to an LS of 4, had high sensitivity and specificity for identifying infections (Dohoo, 2001). Moreover, there is debate about the level that SCC is elevated during the first week after calving (Sargeant et al., 2001), so it was decided to use the second postcalving sample for the LS analysis. Furthermore, due to the power of the study and to avoid making a type II epidemiological error, the $P$-value at which significance was declared was relaxed to $P \leq 0.10$. A type II error occurs when it is declared on the basis of trial results that no true effect exists, when in fact a variable may produce a worthwhile effect (Martin et al., 1987).

Counterintuitive results were obtained when the outcomes indicative of IMI were modeled. We would have hypothesized that treatment and adherence would influence the occurrence of new IMI, which would correspondingly influence LS. Indeed, treatment and duration of sealant adherence were significantly associated with LS at 14 to $21 \mathrm{~d}$ postcalving; however, there was no overall significant association identified between treatment and new environmental streptococcal or coliform IMI. Parameter estimates derived in the final multivariable models for the latter outcomes were highly unstable. Attempts to increase the power by modeling both environmental pathogens together did not yield significant results. It is possible that the sampling regimen and associated definition failed to discern these new IMI. Studies report that environmental infections are generally short in duration (Smith et al., 1985b; Todhunter et al., 1995). Furthermore, the number of observations available for analysis of the discrete IMI variable might have been insufficient in power to detect a statistical difference.

In the final multivariable model for LS at 14 to 21 d postcalving, treatment assigned at drying off had a significant impact on the outcome. Furthermore, duration of sealant adherence to the teat-end was an im- portant consideration in comparing the effects of these treatment groups. Due to the highly skewed distribution of adherence times that were observed, the data supported minimal comparisons among adherence times of 0 to $3 \mathrm{~d}$, and greater than or equal to $4 \mathrm{~d}$. Teats that were coated with only 1 layer of sealant for 0 to 3 d (single:0 to 3) were associated with the highest LS after calving (2.69). Duration of sealant adherence significantly influenced LS. In particular, teats in the single:0 to 3 group were associated with a 0.57 -unit increase in LS after calving, compared with teats in the single:4+ group. This difference could be related to the increased duration of protection from exposure to the environment.

In addition to duration of adherence to the teat-end, the frequency of sealant application was associated with efficacy. Teats that were coated with sealant for 0 to $3 \mathrm{~d}$ using a double sealant application were associated with significantly lower mean LS after calving (-0.80 unit). The thicker coating achieved by a second application may have enhanced the integrity of the seal, thus making it less likely to split at the teat-end. Therefore, if a split formed in the sealant coating at the teatend before falling off, that would have made the teat susceptible to infection sooner than was recorded by observation of overall adherence. Leaking teats have been associated with an increased likelihood of IMI (Schukken et al., 1993; Waage et al., 2001). This has been attributed to the patency of the teat canal, which increases the likelihood of infection (Dingwell et al., 2003). Therefore, if the integrity of the seal is compromised, bacteria from the environment may contaminate and enter the teat canal.

Previous studies that assessed the effect of sealant use on infection status at calving have involved drycow therapy of all quarters (Edinger et al., 2000; Timms, 2001). In the current study conducted in research herds, none of the sealed quarters included in the analysis received dry-cow antibiotics. In the final multivariate model, quarters with high LS at drying off $(\geq 4)$ were significantly associated with a 0.80 -unit increase in LS after calving. This agrees with studies in which the presence of an infection by a major pathogen at drying off increased the likelihood of infection during the dry period and subsequent lactation (Osteras et al., 1999).

Seasonal trends were identified with IMI (Smith et al., 1985b; Todhunter et al., 1995). In the final multivariate model, the season of calving was more predictive than the season of drying off. This could be an indication that infections that occurred during the latter part of the dry period were not adequately controlled by any of the treatments assigned at drying off. Infections incurred during this time are more likely to persist to lactation (Smith et al., 1985b; Todhunter et al., 1995). 
Cows that calved during the spring and summer seasons (March to August) were associated with higher LS after calving. This agrees with findings from other studies, which have reported that more coliform infections occur during these seasons (Smith et al., 1985b; Todhunter et al., 1995). This relationship was attributed to the increased numbers of bacteria found in bedding during the summer for coliforms and other gramnegative bacteria (Smith et al., 1985b; Todhunter et al., 1995). Other sources of contamination were suggested for environmental streptococci infections. In both herds, a higher number of coliform infections were observed within $1 \mathrm{wk}$ after calving. The inclusion of season of calving in the final model may be an indication that treatment at drying off controlled new infections caused by environmental streptococci and coliforms during the early dry period. Moreover, the increased incidence of coliform infections often observed during the latter part of the dry period (Smith et al., 1985b; Todhunter et al., 1995) may not have been prevented by the dry-cow teat sealant.

No statistical associations were identified between any of the recorded teat characteristics and the LS after calving. However, teat-end shape was highly significant in the final multivariate model for new IMI caused by environmental streptococci. Although this may have been a spurious statistical association, some researchers have identified that the teat-end shape is related to the teat canal diameter, which in turn has been associated with the susceptibility to infection (Jorstad et al., 1989; Chrystal et al., 1999). More research needs to be conducted to confirm the biological validity of this finding.

\section{CONCLUSIONS}

The results indicate that duration of sealant adherence to the teat-end should be considered when evaluating the impact of teat sealant treatment at drying off on the level of infection after calving. Double sealant application, cooler seasons, and longer teat lengths were associated with a significant increase in the duration of sealant adherence to the teat-end. Significant differences in the mean duration of adherence were observed between herds, and suggest that certain herd management procedures may be responsible for variation in the duration of adherence.

Results demonstrated that prolonged coverage of the teat-end reduces the LS after calving, and that achieving a durable seal through double application has a beneficial effect. Meaningful conclusions about the effect of treatment on the incidence of new IMI caused by environmental pathogens after calving could not be drawn from this study. The results of this investigation suggest that the use of dry-cow teat sealants have a beneficial impact on the level of infection at calving if a durable seal is formed and remains on the teat-end for a prolonged period at drying off.

\section{REFERENCES}

Acuna Pasuqualini, C. N., G. F. Casasnovas, and C. F. Macazaga. 2006. Effectiveness in the reduction of new intramammary infections in the dry period by the use of an external teat sealant in heifers at prepartum. Pages 258-259 in NMC Annu. Mtg. Proc., Tampa, FL. NMC Inc., Madison, WI.

Bradley, A. J., and M. J. Green. 2001. Aetiology of clinical mastitis in six Somerset dairy herds. Vet. Rec. 148:683-686.

Britt, J. S., and R. Farnsworth. 1996. Here's a system for evaluating teat condition. Hoard's Dairyman (Aug. 25):570-571.

Chrystal, M. A., A. J. Seykora, and L. B. Hansen. 1999. Heritabilities of teat end shape and teat diameter and their relationships with somatic cell score. J. Dairy Sci. 82:2017-2022.

Comalli, M. P., R. J. Eberhart, L. C. Griel, Jr., and H. Rothenbacher. 1984. Changes in the microscopic anatomy of the bovine teat canal during mammary involution. Am. J. Vet. Res. 45:22362242.

Creasey, J., G. Arnott, M. J. Green, and A. J. Bradley. 2002. An investigation of the impact of temperature at the time of application the adherence of an external teat sealant. Pages 222-223 in Proc. 41st Annu. Mtg. NMC Inc., Madison, WI.

Dingwell, R. T., K. E. Leslie, and D. F. Kelton. 2003. Management of the dry cow in control of peripartum disease and mastitis. Vet. Clin. North Am. Food Anim. Pract. 19:157-169.

Dohoo, I. R. 2001. Setting SCC cutpoints for cow and herd interpretation. Pages 10-18 in NMC Annu. Mtg. Proc., Reno, NV. NMC Inc., Madison, WI.

Edinger, D., B. A. Tenhagen, P. Kalbe, G. Klunder, B. Baumgartner, and W. Heuwieser. 2000. Effect of teat dipping with a germicide barrier teat dip in late gestation on intramammary infection and clinical mastitis during the first 5 days post-partum in primiparous cows. J. Vet. Med. A 47:463-468.

Godden, S., P. Rapnicki, S. Stewart, J. Fetrow, A. Johnson, R. Bey, and R. Farnsworth. 2003. Effectiveness of internal teat seal in the prevention of new intramammary infections during the dry and early-lactation periods in dairy cows when used with a dry cow intramammary antibiotic. J. Dairy Sci. 86:3899-3911.

Hemling, T. C., M. Henderson, A. Britten, and N. Hanson. 1998. Effect of teat prep procedures on adherence of a dry cow teat sealant. Pages 265-266 in NMC Annu. Mtg. Proc. NMC Inc., Madison, WI.

Huxley, J. N., M. J. Green, L. E. Green, and A. J. Bradley. 2002. Evaluation of the efficacy of an internal teat sealer during the dry period. J. Dairy Sci. 85:551-561.

Jorstad, A., T. B. Farver, and H. Riemann. 1989. Teat canal diameter and other cow factors with possible influence on somatic cell counts in cow milk. Acta Vet. Scand. 30:239-245.

Liang, K. Y., and S. L. Zeger. 1993. Regression analysis for correlated data. Annu. Rev. Public Health 14:43-68.

Martin, S. W., A. H. Meek, and P. Willeberg. 1987. Veterinary Epidemiology: Principles and Methods. 1st ed. Iowa State University Press, Ames.

Matthews, K. R., R. J. Harmon, B. E. Langlois, W. L. Crist, and R. W. Hemken. 1988. Use of latex teat dip with germicide during the prepartum period. J. Dairy Sci. 71:1940-1946.

McArthur, B. J., T. P. Fairchild, and J. J. Moore. 1984. Efficacy of a latex teat sealer. J. Dairy Sci. 67:1331-1335.

National Mastitis Council (NMC). 1999. Laboratory Handbook on Bovine Mastitis. NMC Inc., Madison, WI.

Osteras, O., V. L. Edge, and S. W. Martin. 1999. Determinants of success or failure in the elimination of major mastitis pathogens in selective dry cow therapy. J. Dairy Sci. 82:1221-1231.

Sanford, C. J., G. P. Keefe, I. R. Dohoo, K. E. Leslie, R. T. Dingwell, L. DesCoteaux, and H. W. Barkema. 2006. Efficacy of using an 
internal teat sealer to prevent new intramammary infections in non-lactating dairy cattle. J. Am. Vet. Med. Assoc. 228:15651573.

Sargeant, J. M., K. E. Leslie, J. E. Shirley, B. J. Pulkrabek, and G. H. Lim. 2001. Sensitivity and specificity of somatic cell count and California Mastitis Test for identifying intramammary infection in early lactation. J. Dairy Sci. 84:2018-2024.

Schukken, Y. H., J. Vanvliet, D. Vandegeer, and F. J. Grommers. 1993. A randomized blind trial on dry cow antibiotic infusion in a low somatic cell count herd. J. Dairy Sci. 76:2925-2930.

Smith, K. L., D. A. Todhunter, and P. S. Schoenberger. 1985a. Environmental mastitis: Cause, prevalence, prevention. J. Dairy Sci. 68:1531-1553.
Smith, K. L., D. A. Todhunter, and P. S. Schoenberger. 1985b. Environmental pathogens and intramammary infection during the dry period. J. Dairy Sci. 68:402-417.

Timms, L. 2001. Field trial evaluations of a novel persistent barrier teat dip for preventing mastitis during the dry period and as a potential substitute for dry cow antibiotic therapy. Pages 262263 in NMC Annu. Mtg. Proc., Reno, NV. NMC Inc., Madison, WI.

Todhunter, D. A., K. L. Smith, and J. S. Hogan. 1995. Environmental streptococcal intramammary infections of the bovine mammary gland. J. Dairy Sci. 78:2366-2374.

Waage, S., S. A. Odegaard, A. Lund, S. Brattgjerd, and T. Rothe. 2001. Case-control study of risk factors for clinical mastitis in postpartum dairy heifers. J. Dairy Sci. 84:392-399. 